\title{
LEYDIG CELL DIFFERENTATION, STEROID METABOLISM BY THE INTERSTITIUM IN VITRO AND THE GROWTH OF THE ACCESSORY SEX ORGANS IN THE RAT
}

\author{
W. N. TSANG, D. LAGY AND P. M. COLLINS \\ Department of Zoology, St Bartholomew's Medical College, \\ Charterhouse Square, London, E.C.1
}

(Received 14th December 1972)

Several workers have studied various parameters as an index of Leydig cell differentiation and attempted to correlate them with the growth of the accessory sex organs. In the prepuberal rat, little correlation seems to have been achieved (see Niemi \& Ikonen, 1963; Clegg, 1966). Others have examined testosterone production in vitro by the immature testis and attempted to correlate this with the increase in weight of the seminal vesicles and prostate gland. In this connection, a good deal of attention has been paid to the production of testosterone in vitro and its apparent regulation by $5 \alpha$-reductase activity. Nayfeh, Barefoot \& Baggett (1966) reported an increase in testosterone production per unit weight of tissue at about the time of sexual maturity and suggested that this might be due mainly to reduced metabolism to $5 \alpha$-androstane- $3 \alpha, 17 \beta$-diol (androstanediol). Inano, Hori \& Tamaoki (1967) found a remarkable increase in the activity of various enzymes associated with testosterone formation from Days 20 to 30 and a marked decline in the yields per testis of androsterone and $3 \alpha, 17 \alpha$-dihydroxy-5 $\alpha$-pregnan-20-one from Days 40 to 60 . The same authors also found a dramatic increase in the weight of the seminal vesicles from Days 50 to 60 . In similar studies, Ficher \& Steinberger (1968) found almost total metabolism of progesterone from birth and confirmed the inverse relationship between testosterone formation and $5 \alpha$-reductase activity. These authors drew attention to 'the importance of Ring A reductases in the process of differentiation of androgen-biosynthetic pathways' (Steinberger \& Ficher, 1969) and later emphasized that 'the physiologic significance of $5 \alpha$-reductase activity during differentiation of the androgen biosynthetic pathways remains to be determined' (Ficher \& Steinberger, 1971). None of these data can be interpreted as being due to the activity of the Leydig cells since this presupposes that the interstitium is the only site of steroid metabolism in the testis. It has been clearly established, however, that in the adult rat and human male, the seminiferous tubules also contain a wide range of enzymes associated with steroid hormone biosynthesis (see Lacy \& Collins, 1973). The question of the relationship between Leydig cell differentiation, steroid metabolism by the interstitial tissue in vitro and the growth of the accessory sex organs thus remains unanswered. 
The work briefly reported on below was carried out in an attempt to throw further light on this problem.

The work was carried out with 30-, 35-, 45-, 56- and 73-day-old rats. In all cases, the testes were excised, weighed and dissected in order to separate the interstitium and tubules (Christensen \& Mason, 1965). Equal amounts (16 to $18 \mathrm{mg}$ wet weight) of interstitial tissue were incubated with $0.1 \mu \mathrm{Ci}\left[4-{ }^{14} \mathrm{C}\right]$ progesterone in Krebs-Ringer bicarbonate at $32.7^{\circ} \mathrm{C}$ for $2 \mathrm{hr}$ ('fixed time' incubations). The incubations were repeated four times with four different rats in each age group. Equal amounts of interstitial tissue (36 mg wet weight) were similarly incubated with $0.2 \mu \mathrm{Ci}\left[4-{ }^{14} \mathrm{C}\right]$ progesterone for a total of $6 \mathrm{hr}$ and samples of
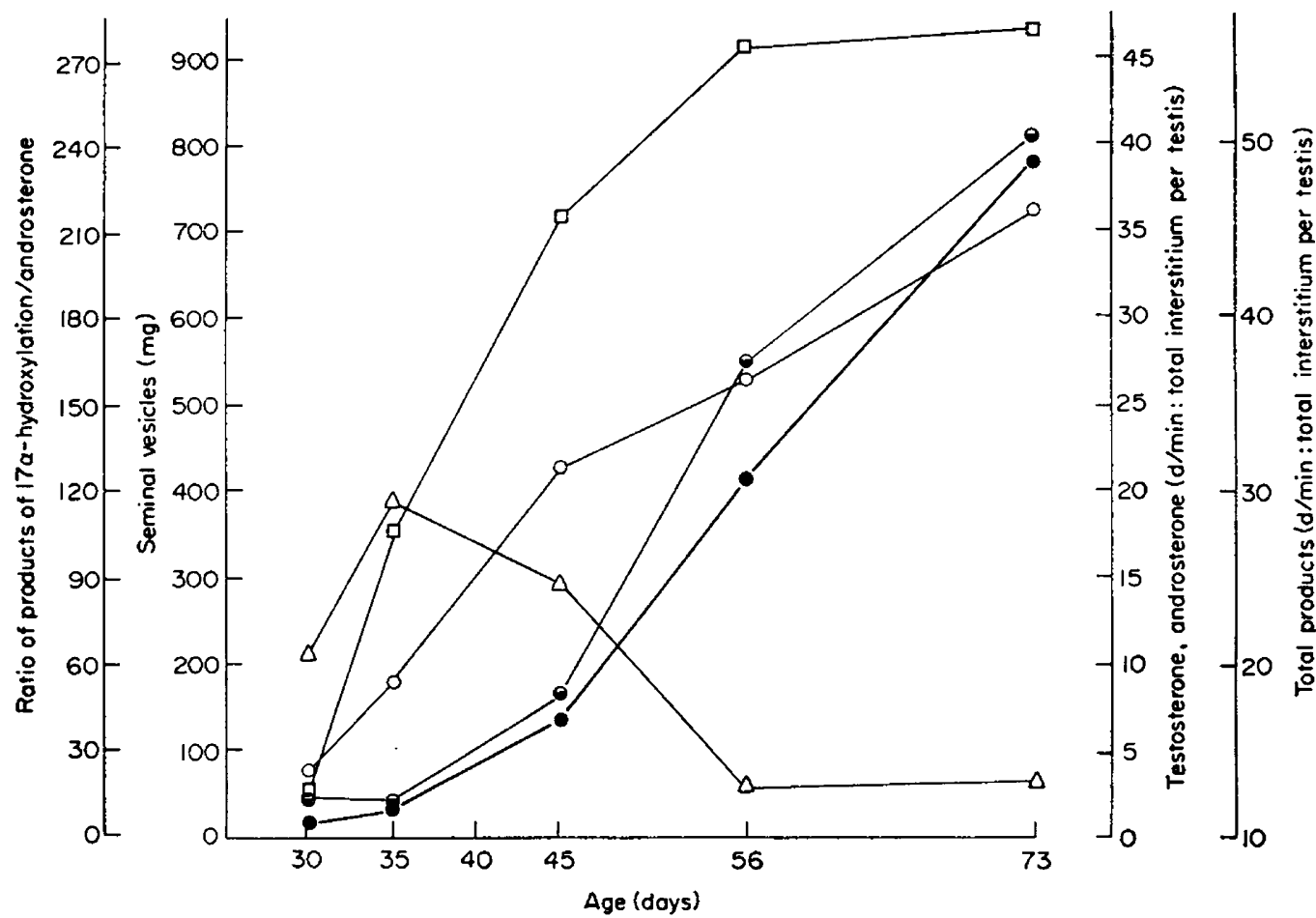

TExT-FIG. 1. Relationships between steroid metabolism by the interstitium in vitro and the weight of the seminal vesicles in the rat during development. - Seminal vesicles; $\odot$, ratio of products of $17 \alpha$-hydroxylation/androsterone; $\Delta$, androsterone $\left(\times 10^{3}\right) ; 0$, testosterone $\left(\times 10^{3}\right) ; \square$, total products.

the medium were withdrawn at progressive intervals of time. The kinetic incubations were carried out on a further three animals in each age group. The steroids were extracted, characterized and identified following the same procedures described in previous work from this laboratory (see Bell, Vinson, Hopkin \& Lacy, 1968). The seminal vesicles, prostate glands and epididymides from each of the above seven animals per age group, together with those from at least three additional rats, were excised and weighed. Samples of the testes were fixed in Bouin's fluid for routine histology and in Baker's fixative for 
Table 1. Observations on the seminal vesicles, Leydig cells and steroid metabolism by the interstitial tissue of the rat during development

\begin{tabular}{l|c|c|c|c|c}
\hline & Day 30 & Day 35 & Day 45 & Day 56 & Day 73 \\
\cline { 2 - 5 } & 15.9 & 30.0 & 132.1 & 410.5 & 777.3 \\
Weight of seminal vesicles & \pm 1.3 & \pm 3.4 & \pm 22.9 & \pm 51.5 & \pm 80.2 \\
(mg) & & & & \\
Presence of secretory material & $-\mathrm{ve}$ & $-\mathrm{ve}$ & $+\mathrm{ve}$ & $+\mathrm{ve}$ & $+\mathrm{ve}$ \\
$\begin{array}{l}\text { Weight of interstitial tissue } \\
\text { per testis (mg) }\end{array}$ & 13.9 & $29 \cdot 4$ & 59.9 & 65.1 & 67.3 \\
$\begin{array}{l}\text { Large amounts of lipid in } \\
\text { Leydig cells }\end{array}$ & \pm 1.9 & \pm 2.7 & \pm 5.0 & \pm 6.0 & \pm 8.4 \\
$\begin{array}{l}\text { Reaction of Leydig cells to } \\
\text { Schultz's test }\end{array}$ & $+\mathrm{ve}$ & $+\mathrm{ve}$ & $-\mathrm{ve}$ & $-\mathrm{ve}$ & $-\mathrm{ve}$ \\
Testosterone/androsterone & $+\mathrm{ve}$ & $+\mathrm{ve}$ & $-\mathrm{ve}$ & $-\mathrm{ve}$ & $-\mathrm{ve}$ \\
ratio (2-hr incubation) & 0.52 & 0.45 & 2.30 & 9.89 & 10.45 \\
& \pm 0.19 & \pm 0.13 & \pm 0.81 & \pm 1.76 & \pm 0.92 \\
\hline
\end{tabular}

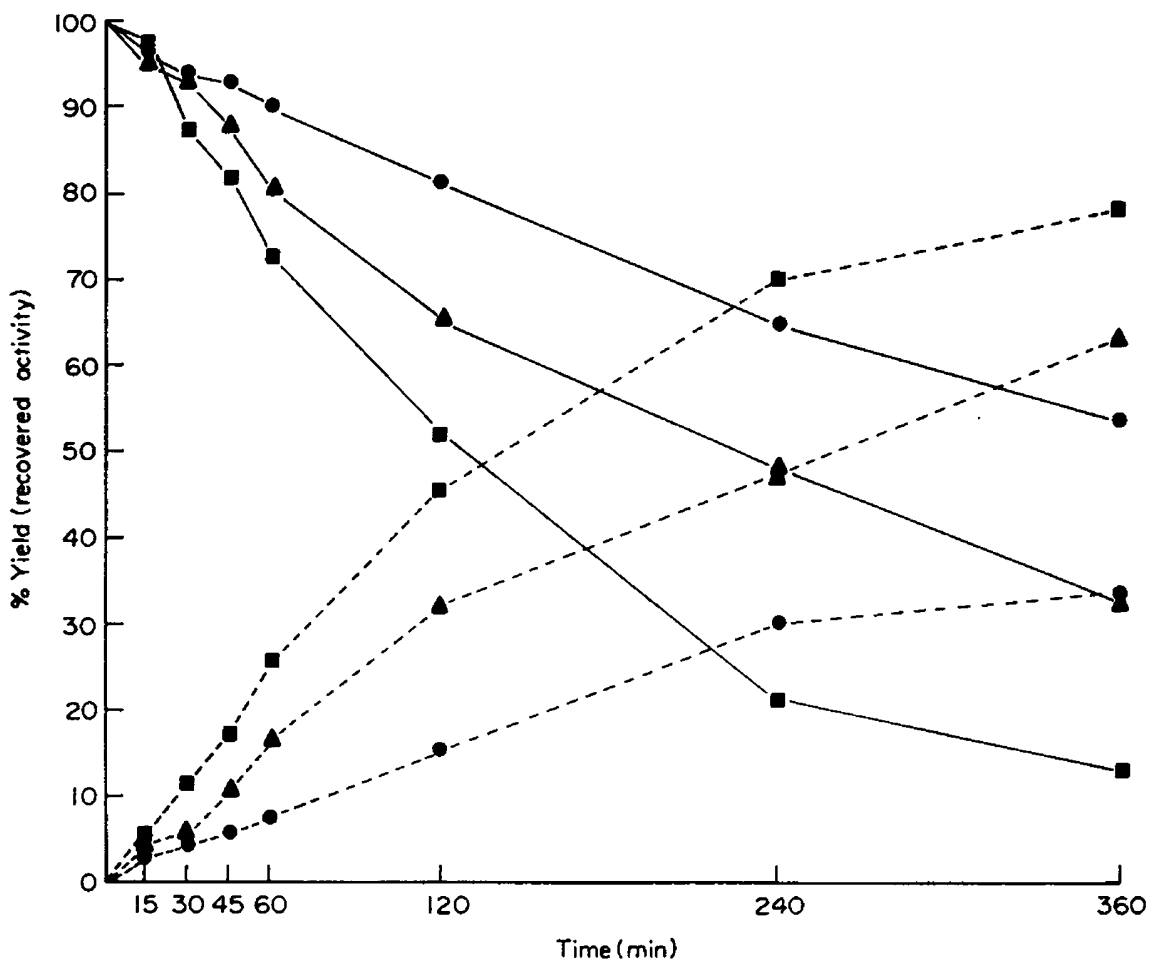

TexT-FIG. 2. Metabolism of $\left[4-{ }^{14} \mathrm{C}\right]$ progesterone $(-)$ by the interstitium in vitro and the sum of the yields of 17a-hydroxyprogesterone, androstenedione and testosterone $(----) . \bullet, 30$ days; $\triangle, 35$ days; $\square, 45$ days. 
demonstrating lipids (Sudan Black B) and unsaturated sterols (Schultz's test) as in previous work (see Collins \& Lacy, 1969).

The weight of the seminal vesicles increased gradually from Days 30 to 35 and then rose sharply from Days 35 to 45 , followed by a further marked increase from Days 45 to 73 (Text-fig. 1). The steep rise from Day 35 to Day 45 was accompanied by a number of changes in the interstitial tissue and Leydig cells. During this period, the weight of the interstitium per testis reached the adult range while the lipid in the Leydig cells was reduced to the low level typical of mature rats and gave a negative response to Schultz's test (Table 1).

In both the 'fixed time' and the kinetic incubations, the principal metabolites obtained were 17 $\alpha$-hydroxyprogesterone, androstenedione, testosterone and androsterone; the total yield of all other metabolites was less than $10 \%$ of the recovered activity. In the kinetic incubations, a definite and progressive change in the rate of progesterone metabolism was obtained from Day 30 to Day 45 and a corresponding increase in products formed by $17 \alpha$-hydroxylation (Textfig. 2). In the 'fixed time' incubations, no significant differences in the levels of progesterone metabolism were recorded among the age groups studied. When the metabolism was expressed in terms of the weight of interstitium per testis, however, there was a progressive increase (Text-fig. 1). These results demonstrate that steroid metabolism in vitro by the interstitium of the immature rat is influenced both by an increase in the rate of metabolism of progesterone and by the increase in the weight of the tissue.

There was almost a linear increase in the yield of testosterone, when expressed in terms of the interstitial tissue weight per testis, from Day 30 onwards. The initial increase occurred at a time when androsterone levels were at their highest (Text-fig. 1). Hence, the increased testosterone production at this stage was not specifically related to a decline in $5 \alpha$-reductase activity but to the increase in the rate of metabolism of progesterone and the gain in weight of the interstitium. From Day 35 onwards, the increase in testosterone production was accompanied by a rapid decline in $5 \alpha$-reductase activity reflected in markedly reduced yields of androsterone and a reversal in the testosterone/androsterone ratio (Table 1).

The increase in testosterone production from about Day 35 onwards covered the period when the seminal vesicles entered their main growth phase and the interstitium and Leydig cells assumed various adult characteristics (see Table 1). There was then a good correlation between testosterone production in vitro and events occurring in vivo. This suggests that from about Day 35 onwards, there was increased secretion of testosterone, a view which generally is in accord with measurements on blood androgen levels in the prepuberal rat (Knorr, Vanha-Perttula \& Lipsett, 1970). In the present work, the reduced yields of androsterone in vitro might have been due to a decline in substrate availability within the cells rather than to an intrinsic decline in the concentration of $5 \alpha-$ reductase. While this seems inconsistent with the results of previous workers, interpretation in these cases was complicated by the use of preparations derived from whole testis (Nayfeh et al., 1966; Inano et al., 1967; Ficher \& Steinberger, 1968). Studies complementary to the present work have failed to demonstrate the formation of androsterone in isolated seminiferous tubules (Tsang, Collins 
\& Lacy, 1973). On this basis, relative yields of androsterone from older testes would decline, irrespective of the amount of $5 \alpha$-reductase present, as interstitial tissue becomes diluted with a greater proportion of the tubular elements.

When the ratio of testosterone to androsterone was considered together with the growth curve of the seminal vesicles, a greater degree of correlation was obtained (Table 1) than with testosterone alone (Text-fig. 1). The correlation was more precise when the ratio between the sum of the products of $17 \alpha$ hydroxylation and androsterone was similarly plotted (Text-fig. 1). While both ratios may reflect the secretion of testosterone, metabolites such as androsterone may themselves be secreted and the changing ratio of such metabolites may be responsible for the growth of the seminal vesicles. A similarly high correlation between steroid metabolism in vitro and the growth of the prostate and epididymides was also obtained.

It is a pleasure to acknowledge the financial support of the Wellcome Trust, Schering Chemicals and the Joint Research Board of St Bartholomew's Hospital and Medical College.

\section{REFERENCES}

Bell, J. B. G., Vinson, G. P., Hopkin, D. J. \& LACY, D. (1968) Pathways for androgen biosynthesis from $\left[7 \alpha_{-}{ }^{3} \mathrm{H}\right]$ pregnenolone and $\left[4-{ }^{14} \mathrm{C}\right]$ progesterone by rat testis interstitium in vitro. Biochim. biophys. Acta, 164, 421 .

Christensen, A. K. \& Mason, N. R. (1965) Comparative ability of seminiferous tubules and interstitial tissue of rat testes to synthesize androgens from progesterone-4- ${ }^{14} \mathrm{C}$ in vitro. Endocrinology, 76, 646.

GLegg, E. J. (1966) Pubertal growth in the Leydig cells and accessory reproductive organs of the rat. 7. Anat. 100, 369.

Collins, P. M. \& LACY, D. (1969) Studies on the structure and function of the mammalian testis. II. Cytological and histochemical observations on the testis of the rat after a single exposure to heat applied for different lengths of time. Proc, R. Soc. B, 172, 17.

Ficher, M. \& Steinberger, E. (1968) Conversion of progesterone to androsterone by testicular tissue at different stages of maturation. Steroids, 12, 491.

Ficher, M. \& Steingerger, E. (1971) In vitro progesterone metabolism by rat testicular tissue at different stages of development. Acta endocr., Copenh. 68, 285.

INANO, H., HORI, Y. \& TAMAOKI, B. (1967) Effect of age on testicular enzymes related to steroid bioconversion. Ciba Fdn Colloq. Endocr. 16, 105.

Knorr, D. W., Vanha-Perttula, T. \& Lipsett, M. B. (1970) Structure and function of rat testis through pubescence. Endocrinology, 86, 1298.

LACY, D. \& Collins, P. M. (1973) Hormones and contraception in the male and the relative merits of hormonal control and vasectomy. F. Reprod. Fert. Suppl. 18 (in press).

NAYfeh, S. N., Barefoot, S. W. \& Baggett, B. (1966) Metabolism of progesterone by rat testicular homogenates. II. Changes with age. Endocrinology, 78, 1041.

NIEMI, M. \& IKONEN, M. (1963) Histochemistry of the Leydig cells in the postnatal prepubertal testis of the rat. Endocrinology, 72, 443.

Steingerger, E. \& Ficher, M. (1969) Differentiation of steroid biosynthetic pathways in developing testes. Biol. Reprod. Suppl. 1, 119.

Tsang, W. N., Collins, P. M. \& Lacy, D. (1973) Steroid metabolism by the seminiferous tubules in vitro and spermatogenesis in the developing rat. F. Reprod. Fert. 34, 513. 